ORION, Vol. 12, No. 1/2, pp. 43-55

ISSN 0259-191-X

\title{
AN ANALYSIS OF KEY RDP ISSUES AND PROPOSED SUPPORT BY THE STATISTICAL PROFESSION
}

\author{
CF SMIT \\ University of Pretoria \\ South Africa
}

\section{INTRODUCTION}

In 1994, after years of disunity and bitter human relationships, we had a miraculous and peaceful transition of government. The Government of National Unity adopted a comprehensive programme to rebuild South Africa, the so called Reconstruction and Development Programme (RDP). This programme has now been accepted by the South African society at large and much has been said and written about it in the South African community and in the media. Most organizations and societies have givens special consideration to their individual contributions to the unfolding of the RDP. Today's events are just another proof of this fact.

The purpose of this paper is to analyse discussion in the written media regarding the RDP, to assess where this discussion is taking place and what are the major issues being discussed, on the one hand, and on the other hand to assess where the statistical community is located, what they are working on and what likely contribution the statistical profession can make to key RDP issues addressed in the media. 


\section{A SURVEY OF RDP RELATED PUBLICATIONS}

A literature search on RDP related papers in South African publications during the past two years proved to be very fruitful. We found without any difficulty a list of 442 papers which in some or other sense refer to the RDP. A selected subset of 240 papers in 53 journals and other publications rendered a good basis for a contents analysis of matters that people who express their opinion in the written media, consider to be important. Table 1 summarizes the frequency of articles referring to the RDP for each journal.

This list is by no means exhaustive or complete and many publications can easily be found which directly or indirectly address RDP related issues. However, the wide spectrum of journals clearly illustrates the general interest in and support for the philosophy of the RDP as an instrument for rebuilding the country. Since reconstruction implies cost it is perhaps not surprising that the major discussion takes place in the financial journals, but what does surprise is the relative low frequency of discussion in journals focusing on development, housing, agriculture and human resources.

Next, an analysis is made of the key issues addressed in the papers and the relative weights of each issue are determined in terms of the number of references in papers to it. This is summarized in Table 2. This table suggests that the discussion in the literature is fairly evenly spread across the various aspects of the RDP, except for community development. That community development is discussed in only $6.4 \%$ of the articles seems to contradict the essence of the RDP, which is surely the development of the under-privileged community. Of course, many of the papers discussing finance, infrastructure and socio-economic matters may well implicitly focus on community issues. 


\begin{tabular}{|l|c|l|c|}
\hline JOURNAL & F & JOURNAL & F \\
\hline Finansies en Tegniek & 48 & Finance Week & 32 \\
\hline Financial Mail & 22 & African Business & 11 \\
\hline Civil Engineering Contractor & 11 & $\begin{array}{l}\text { Munisipale en Open-bare } \\
\text { Dienste }\end{array}$ & 11 \\
\hline Municipal Engineer & 9 & SA Builder & 7 \\
\hline Work in Progress & 7 & Aambeeld & 4 \\
\hline Information Technology Review & 4 & Marketing Mix & 4 \\
\hline RSA Review & 4 & $\begin{array}{l}\text { South African Construction } \\
\text { World }\end{array}$ & 4 \\
\hline Transport Management & 4 & $\begin{array}{l}\text { Wood Southern Africa and } \\
\text { Timber Times }\end{array}$ & 4 \\
\hline Development Southern Africa & 3 & Farmer's Weekly & 3 \\
\hline Housing in Southern Africa & 3 & $\begin{array}{l}\text { Human Resources } \\
\text { Management }\end{array}$ & 3 \\
\hline Imiesa & 3 & Landbouweekblad & 3 \\
\hline Sanlam's Economic Survey & 3 & $\begin{array}{l}\text { South African Mechanical } \\
\text { Engineer }\end{array}$ & 3 \\
\hline South African Labour Bulletin & 2 & Accountancy SA & 1 \\
\hline Africa Insight & 1 & Agenda & 1 \\
\hline Agrekon & 1 & Arbor & 1 \\
\hline Chemical Technology & 1 & Civil Engineering & 1 \\
\hline Computer Graphics & 1 & Concrete & 1 \\
\hline Electron & 1 & Entrepreneur & 1 \\
\hline Indicator South Africa & 1 & Leadership SA & 1 \\
\hline $\begin{array}{l}\text { Nedbank Quarterly Guide to the } \\
\text { Economy }\end{array}$ & 1 & NTCl Current Affairs Update & 1 \\
\hline People Dynamics & 1 & Plastics Southern Africa & 1 \\
\hline $\begin{array}{l}\text { South African Journal of } \\
\text { Economics }\end{array}$ & 1 & $\begin{array}{l}\text { South African Journal of } \\
\text { Library and Information }\end{array}$ & 1 \\
\hline South African Journal of Science & 1 & South African Mining Worid & 1 \\
\hline South African Sugar Journal & 1 & South African Transport & 1 \\
\hline South African Outlook & 1 & $\begin{array}{l}\text { Strategic Review for } \\
\text { Southern Africa }\end{array}$ & 1 \\
\hline Textile Industries Dyegest & 1 & Transformation & 1 \\
\hline Wouthern Africa & 1 & TOTAL & 240 \\
\hline
\end{tabular}

Table 1: Frequency of articles in journals referring to the RDP during 1994-1995 


\begin{tabular}{|c|c|}
\hline ASPECT & PERCENTAGE \\
\hline 1. RDP: GENERAL & 19.7 \\
\hline 2. FINANCIAL AND ECONOMICAL MATTERS & 27.9 \\
\hline 3. INFRASTRUCTURE & 20.9 \\
\hline 4. SOCIO-ECONOMIC MATTERS & 25.2 \\
\hline 5. COMMUNITY DEVELOPMENT & 6.4 \\
\hline
\end{tabular}

Table 2: Relative weights of references in papers to key RDP issues

The following tables gives a breakdown of each aspect into its elements, ir decreasing order of relative weights or percentages. The percentages ir brackets reflect the relative overall weights (over all aspects of Table 2) of eact issue.

\begin{tabular}{|l|c|}
\hline ELEMENT & PERCENTAGE \\
\hline Policy, priorities & $27.7(5.5)$ \\
\hline Financing and spending & $21.5(4.2)$ \\
\hline Role of Central Government & $20.0(3.9)$ \\
\hline Role of Province & $15.4(3.0)$ \\
\hline Philosophy & $9.2(1.8)$ \\
\hline Role of Local Government & $6.2(1.2)$ \\
\hline
\end{tabular}

Table 3.1: Breakdown of RDP: general into its elements

\begin{tabular}{|l|c|}
\hline ELEMENT & PERCENTAGE \\
\hline Private sector business & $21.7(6.1)$ \\
\hline Economy (general) & $20.7(5.8)$ \\
\hline Banking, monetary, fiscal & $15.2(4.2)$ \\
\hline Budget & $10.9(3.0)$ \\
\hline Finance (general) & $9.8(2.4)$ \\
\hline Tax & $5.4(1.5)$ \\
\hline Labour and Productivity & $5.4(1.5)$ \\
\hline Marketing & $4.3(1.2)$ \\
\hline Industry, mining & $4.3(1.2)$ \\
\hline Competitiveness & $2.2(0.6)$ \\
\hline
\end{tabular}

Table 3.2: Breakdown of Financlal and Economic Matters 


\begin{tabular}{|l|c|}
\hline ELEMENT & PERCENTAGE \\
\hline Agriculture & $15.9(3.3)$ \\
\hline Building and Construction & $15.9(3.3)$ \\
\hline Information, management & $11.6(2.4)$ \\
\hline Water supply & $11.6(2.4)$ \\
\hline Energy & $10.1(2.1)$ \\
\hline Transport & $10.1(2.1)$ \\
\hline Forestry & $7.2(1.5)$ \\
\hline Roads & $7.2(1.5)$ \\
\hline Ecology, environment & $5.8(1.2)$ \\
\hline Communication & $4.3(0.9)$ \\
\hline
\end{tabular}

Table 3.3: Breakdown of infrastructure

\begin{tabular}{|l|c|}
\hline ELEMENT & PERCENTAGE \\
\hline Housing & $30.1(7.6)$ \\
\hline Job creation and training & $18.1(4.5)$ \\
\hline Upliftment of communities & $10.8(2.7)$ \\
\hline Water & $10.8(2.7)$ \\
\hline Education and nutrition & $7.2(1.8)$ \\
\hline Sanitation & $7.2(1.8)$ \\
\hline Development of human resources & $6.0(1.5)$ \\
\hline Demography & $4.8(1.2)$ \\
\hline Health & $3.6(0.9)$ \\
\hline Tariffs and payment for service & $1.2(0.3)$ \\
\hline
\end{tabular}

Table 3.4: Breakdown of socio-economic matters

\begin{tabular}{|l|c|}
\hline ELEMENT & PERCENTAGE \\
\hline Land reform & $52.4(3.3)$ \\
\hline Rural development & $19.0(1.2)$ \\
\hline Urban development & $14.3(0.9)$ \\
\hline Development agencies & $9.5(0.6)$ \\
\hline Development priorities & $4.8(0.3)$ \\
\hline
\end{tabular}

Table 3.5: Breakdown of Community Development 
With regard to the breakdown of "RDP: General", the relative low level of attention that the role of provinces and especially local governments have received, catches the eye. One would expect that the high level of attention given to the philosophy, policy and priorities of the RDP will spill over to these two elements.

The breakdown of "Economic and Financial Matters" creates the impression that by far the major focus has been on the macro economic level. One might wish that the discussion will now filter down to a micro level. The specific roles that mining and other industries could play, also appears to need being addressed now. Labour and productivity issues should receive much more attention in literature. It is further clear that South Africans are far from the point of taking aggressive measures to improve our position on overseas markets, if the element of "marketing" is to be taken as an indication.

The breakdown of the "Infrastructure" given in Table 3.3 suggests a well balanced discussion of items. It should be noted that "water supply" is actually discussed more often in RDP literature than the relative weight of $2.4 \%$ indicated in Table 3.3, since it is also included in Table 3.4 with a weight of $2.7 \%$ resulting in an overall weight of $5.1 \%$.

With regard to the relative weights of "Socio-economic Matters" one is surprised by the lack of attention given to education, nutrition and development of human resources. Hopefully in future these vital elements in the well being of the nation will be subjected to due efforts in RDP related research. One would also expect health to rank higher on the scale that was derived in this literature study.

Finally, looking at Table 3.5, one is struck by the high level of attention paid to land reform, a very sensitive issue. Note however, that the weight of $52.3 \%$ is relative to "Community development" matters and that its overall weight is 
actually only $3.3 \%$. As said before, development of urban and rural communities has not yet been given due attention, at least as far as literature discussion is concerned.

\section{THE SOUTH AFRICAN STATISTICAL PROFESSION}

The discipline of statistics is not well known among the public at large. In an official publication of the South African Statistical Association, called "A Career in Statistics", which is distributed among pupils and students throughout the country, statistics is described as follows:

"Statistics makes sense of numbers. This description means that Statistics includes all ways in which information is collected, processed and interpreted. These activities are based on sound scientific principles, particularly those of the queen of sciences: Mathematics".

We wish to emphasise that statistics is not merely concerned with tables and graphs of everyday events such as car accidents, rainfall, births and deaths. Statistical science is applied in practically every field of endeavour where measurements of some kind are made and where forecasts and other decisions are needed. Examples are abundant: In the financial and economic worked, in medicine and biology, in industry and engineering and in education and psychology.

The statistical professional is to a large degree represented in the South African Statistical Association (SASA). Therefore, it might be worthwhile to analyse the membership list which has just been updated. At present SASA comprises some 400 members of which more than $70 \%$ have at least a master's degree in statistics. Although more than $50 \%$ of its members are working in an academic environment, the fields of application varies over a very wide range. Table 4 summarizes the fields of application over the nine provinces of South Africa. 


$\begin{array}{lll}\text { P1 }=\text { Gauteng } & \text { P2 }=\text { Mpumalanga } & \text { P3 }=\text { Free State } \\ \text { P4 }=\text { Northern Cape } & \text { P5 }=\text { North West } & \text { P6 }=\text { Western Cape } \\ \text { P7 }=\text { Kwazulu-Natal } & \text { P8 }=\text { Eastern Cape } & \text { P9 }=\text { Northern Province }\end{array}$

\begin{tabular}{|l|r|r|r|r|r|r|r|r|}
\hline APPLICATION & $\begin{array}{r}\text { P1 } \\
\text { P2 }\end{array}$ & $\begin{array}{r}\text { P3 } \\
\text { P4 }\end{array}$ & P5 & P6 & P7 & P8 & P9 & TOTAL \\
\hline Math Statistics \& Mathematics & 51 & 11 & 6 & 16 & 12 & 6 & 4 & 106 \\
\hline Medical \& Life Sciences & 17 & 8 & 2 & 16 & 6 & & & 49 \\
\hline Biological Sciences & 13 & 3 & 4 & 14 & 7 & 4 & 1 & 46 \\
\hline Agricultural Sciences & 16 & 4 & 2 & 6 & 6 & 1 & & 35 \\
\hline Engineering & 24 & 1 & & 7 & & & 1 & 33 \\
\hline Economics \& Economic Theory & 20 & 1 & 3 & 5 & 1 & 1 & 2 & 32 \\
\hline Education & 17 & 3 & & 3 & 5 & 3 & & 31 \\
\hline Business Management & 13 & & & 8 & 1 & 2 & & 24 \\
\hline Humanities & 19 & & & 1 & 3 & & & 23 \\
\hline Finance \& Banking & 16 & & & 4 & 2 & & & 22 \\
\hline Pharmaceutical Sciences & 4 & 4 & 2 & 6 & 2 & 3 & & 21 \\
\hline Information \& Man. Systems & 11 & 1 & & 7 & & & & 19 \\
\hline Marketing \& Publicity & 9 & 1 & 1 & 5 & 1 & 1 & & 18 \\
\hline Earth Sciences & 13 & & 1 & 3 & 1 & & & 18 \\
\hline Computer Science & 13 & & 1 & 1 & 1 & & 1 & 17 \\
\hline Psychology & 10 & & 2 & 3 & 1 & & & 16 \\
\hline Manufacturing & 10 & & & 5 & & & & 15 \\
\hline Public Health / Health Services & 6 & 2 & & 6 & 1 & & & 15 \\
\hline Actuarial Sciences & 5 & & & 9 & & & & 14 \\
\hline Demography & 10 & & & 1 & 1 & 1 & 1 & 14 \\
\hline Chemical Sciences & 7 & 2 & & 2 & & 2 & & 13 \\
\hline Environmental Sciences & 6 & & 1 & 4 & 2 & & & 13 \\
\hline Defence & 5 & & 1 & 4 & & & & 10 \\
\hline Fisheries \& Forestry & 2 & & 1 & 3 & 1 & & & 7 \\
\hline Accountancy & 3 & & & 2 & & 1 & & 6 \\
\hline Energy & 3 & & 1 & 1 & & & & 5 \\
\hline Physical Sciences & 1 & & & 2 & & 1 & 1 & 5 \\
\hline Town \& Regional Planning, & 2 & 1 & & 1 & & & & 4 \\
Architecture & & & & & & & & \\
\hline Communication Systems & 1 & & & 1 & 1 & & & 3 \\
\hline Transport & 3 & & & & & & & 3 \\
\hline Law & 1 & & & & & & & 1 \\
\hline Sociology & 11 & 3 & & & 1 & & & 15 \\
\hline Other & 343 & 45 & 28 & 146 & 56 & 26 & 10 & 654 \\
\hline TOTAL & $(52)$ & $(7)$ & $(4)$ & $122)$ & $(9)$ & $(4)$ & 121 & \\
\hline & & & & & & \\
\hline
\end{tabular}

Table 4: Application fields of SASA members over provinces 
The numbers in the table represent SASA members. However, it should be remembered that some SASA members gave more than one field of application and for others no information with regard to application field is available. The totals of the rows and columns should therefore not be regarded as separate individuals, but rather as weights for the different categories. The figures in brackets in the final row represent the percentages for the different provinces.

Some of the most important observations from Table 4 are as follows:

1. The statistical community offers services over a wide range of applications. The fields of highest concentration (Mathematical Statistics, the Medical and Biological sciences, Agriculture, Engineering, Economics and Education) can certainly serve the needs of the country in those fields, but the diversity of applications is the most important factor to illustrate the valuable contribution that can be made by statisticians.

2. More than $50 \%$ of available statistical support in terms of applications is concentrated in the Gauteng province and only the Western Cape (with $22 \%)$ comes close to that.

3. The lack of available support in some provinces should not be a serious drawback, since it is not uncommon for statisticians in a province in the northern part of the country to render services in a southern province or vice versa.

\section{A CHALLENGE AND OPPORTUNITY}

During 1994 the South African Statistical Association gave thought as to how it might support the RDP. It was soon realised that statisticians can make a valuable contribution with regard to the planning and execution of the RDP. Scientific surveys for assessing and prioritising needs can be undertaken. Quantification of change and effects of electrification, education and housing are natural areas where the application of statistics can have an impact. Other areas are experimental design which is vital for the optimal use of our limited 
natural and human resources; stochastic and econometric modelling are powerful and proved techniques to help manage the complexities of our modern world and biostatistics and epidemiology can address the health needs of people not only from South Africa but also from the rest of Africa. Agencies already exist for rendering consultation services relating to surveys and other statistical needs over a broad field. These agencies and also tertiary training institutions are prepared to assist in the training of underprivileged people who would like to attain a basic knowledge of statistics or even to expand their statistical knowledge.

Time does not permit us to elaborate on all the available possibilities, but the exposition of application fields given above makes is absolutely clear that we do have the tools to make a significant contribution to the success of the RDP. It now only remains for us to reach out and take the opportunity in our hands. The display of Figure 1 sums it all up: The discrepancies and imbalances in the relative weights on the left and right sides of the graph are not really relevant. The message is: Come together and let the needs and the profession meet for the benefit of our country. I know that many South African statisticians are prepared to accept co-ownership of the RDP. I dare say that RDP officials should realize that statisticians have a strong desire to contribute. If I can conclude with a play on words, I would like to state:

AN OPPORTUNITY - for the RDP office!

A CHALLENGE - - for the statistical community!

\section{ACKNOWLEDGEMENTS}

The auther gratefully mentions the names of a few colleagues in the statistical profession who assisted in the preparation of this talk: Prof. FL Vivier, Mr. D Herbst and Prof. J Fresen. 


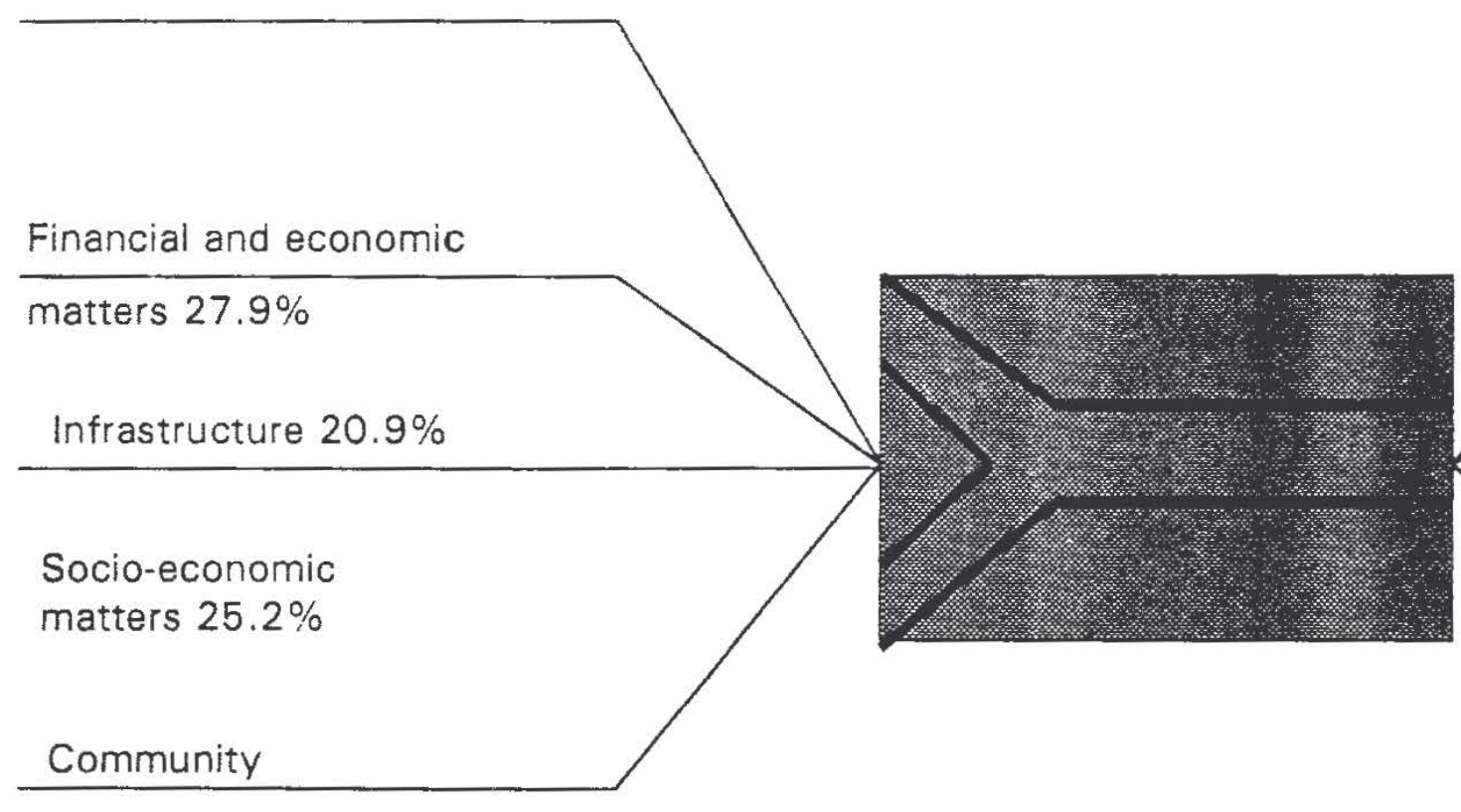

development $6.4 \%$

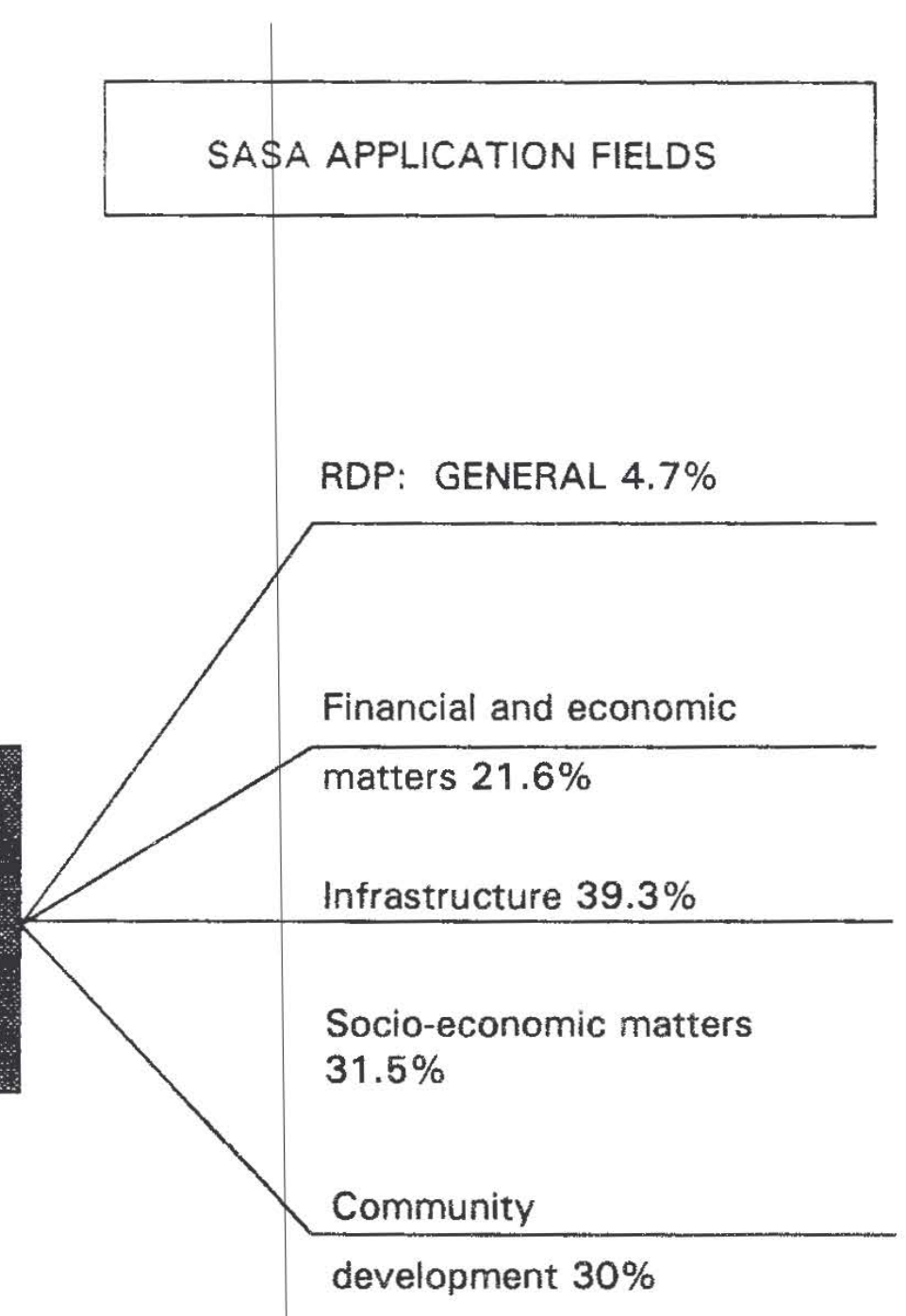

Figure 1: Link between RDP literature and SASA application fields 